\title{
Impact of forest management on wild boar (Sus scrofa) population in south Lithuania
}

\author{
Tomas Barkauskas ${ }^{2}$, \\ Loreta Griciuviene $\dot{e}^{1}$, \\ Olgirda Belova²,
}

Nomeda Bratčikoviené ${ }^{3}$

${ }^{1}$ Vytautas Magnus University,

K. Donelaičio St. 58,

Kaunas 44248, Lithuania

${ }^{2}$ Institute of Forestry LAMMC,

Liepu St. 1, Girionys 53101,

Kaunas District, Lithuania

${ }^{3}$ Vilnius Gediminas Technical University,

Sauletekio Av. 11,

Vilnius 10223, Lithuania
We assessed the effect of the investigated felling types on the abundance of the wild boar population in south Lithuania. The study was carried out in the southern part of Prienai forest, Punia pine forest, and Kalviai forest, all located in southern Lithuania. The data on the number of the wild boar population and the hunting dynamics were gathered from six hunting seasons, from 2008 to 2014. Our results highlighted that some types of felling had negative effects on the density of the wild boar population in south Lithuania. We observed that changes in the wild boar population were not only affected by the felling of the current year, but also by that of the previous year. Further analysis of data collected over a larger area is needed to check these findings.

Keywords: Sus scrofa, forest management, south Lithuania

\section{INTRODUCTION}

The wild boar (Sus scrofa) is one of the most successful, abundant, and widespread species of wild ungulates in Europe (Apollonio et al., 2010; Lombardini et al., 2017; Lacolina et al., 2018). A high level of adaptability of this species to various environmental conditions and their successful expansion in Europe are explained by a high reproductive capacity, adaptability to a variety of habitats, dispersal potential, and high plasticity of wild boar (opportunistic, omnivorous diet) (Cahill et al., 2003; Gethöffer et al., 2007; Herrero et al., 2008; Ballari, Barrios-García, 2014). In most European countries, wild boar is the most widely hunted big

\footnotetext{
* Corresponding author. Email: tomas.barkauskas40@gmail.com
}

game (Nores et al., 2008; Apollonio et al., 2010). The Central European wild boar (Sus scrofa) is considered one of the subspecies inhabiting the Baltic countries (Baleišis et al., 2003). Climatic trends, human impacts, and ecological factors influence the distribution and abundance of the ungulates (Acevedo et al., 2005). According to some authors, the distribution of ungulate species depends on the habitat structure and suitability (Cahill et al., 2003; Acevedo et al., 2005, 2006). Considerable research has been conducted into the impact of intense hunting on wild boar dispersal (Keuling et al., 2008; Tolon et al., 2009; Thurfjell et al., 2013; Massei et al., 2014), but the data on the assessment of the impact of forestry on the wild boar population are still scarce. Disturbing forest management influences habitat suitability, population 
density, behaviour, and movement of the ungulates (Long et al., 2008; Avgar et al., 2015; Stergar, Jerina, 2017). Investigation of demographic measurements is important in understanding how populations respond to forest management. The purpose of this study is to analyze how changes in forest management could affect the wild boar population in Lithuania.

\section{MATERIALS AND METHODS}

The study was carried out in the southern part of Prienai forest, Punia pine forest, and Kalviai forest, all located in southern Lithuania (Fig. 1). We analysed the effects of felling intensity and felling types on the wild boar population. This research was based on two primary types of felling, which were divided into smaller categories: final felling (clear, clear salvage, shelterwood cutting, and selective felling) and intermediate felling (pre-commercial thinning, commercial thinning, selective salvage cuttings, and special felling). The data on the population number of wild boar and the hunting dynamics were gathered from six hunting seasons, from 2008 to
2014. The data on the number and abundance of animals were obtained from the official census of the Ministry of Environment and from the censuses of different hunting areas.

The population density of wild boar $(T)$ was calculated by the following formula (Navasaitis and Petelis, 1998):

$$
T={ }^{G} / P
$$

where: $G$ - the number of animals in the territory, individuals, $P$ - a territory unit of 1,000 ha.

The relationship between the population density of wild boar and changes in forest management was analysed using Pearson productmoment correlation coefficient that measures the strength and direction of a linear association. Statistical analysis was performed using the Statistical Software R.

\section{RESULTS AND DISCUSSION}

We analyzed the effect of the investigated felling types on the abundance of the wild boar population in south Lithuania. Variables that affect wild boar population abundance are given in the Table.

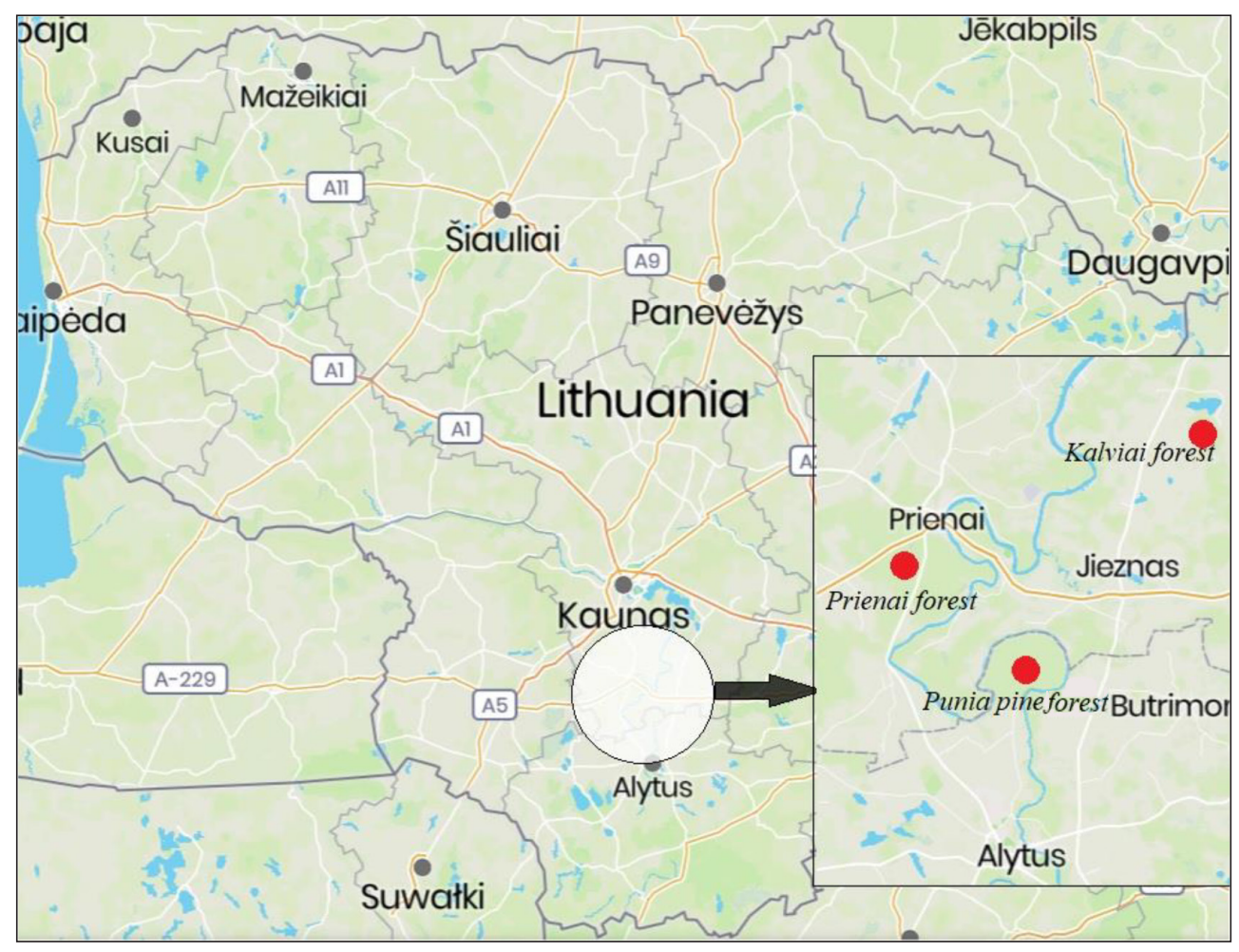

Fig. 1. Map of the study area in the southern part of Lithuania 


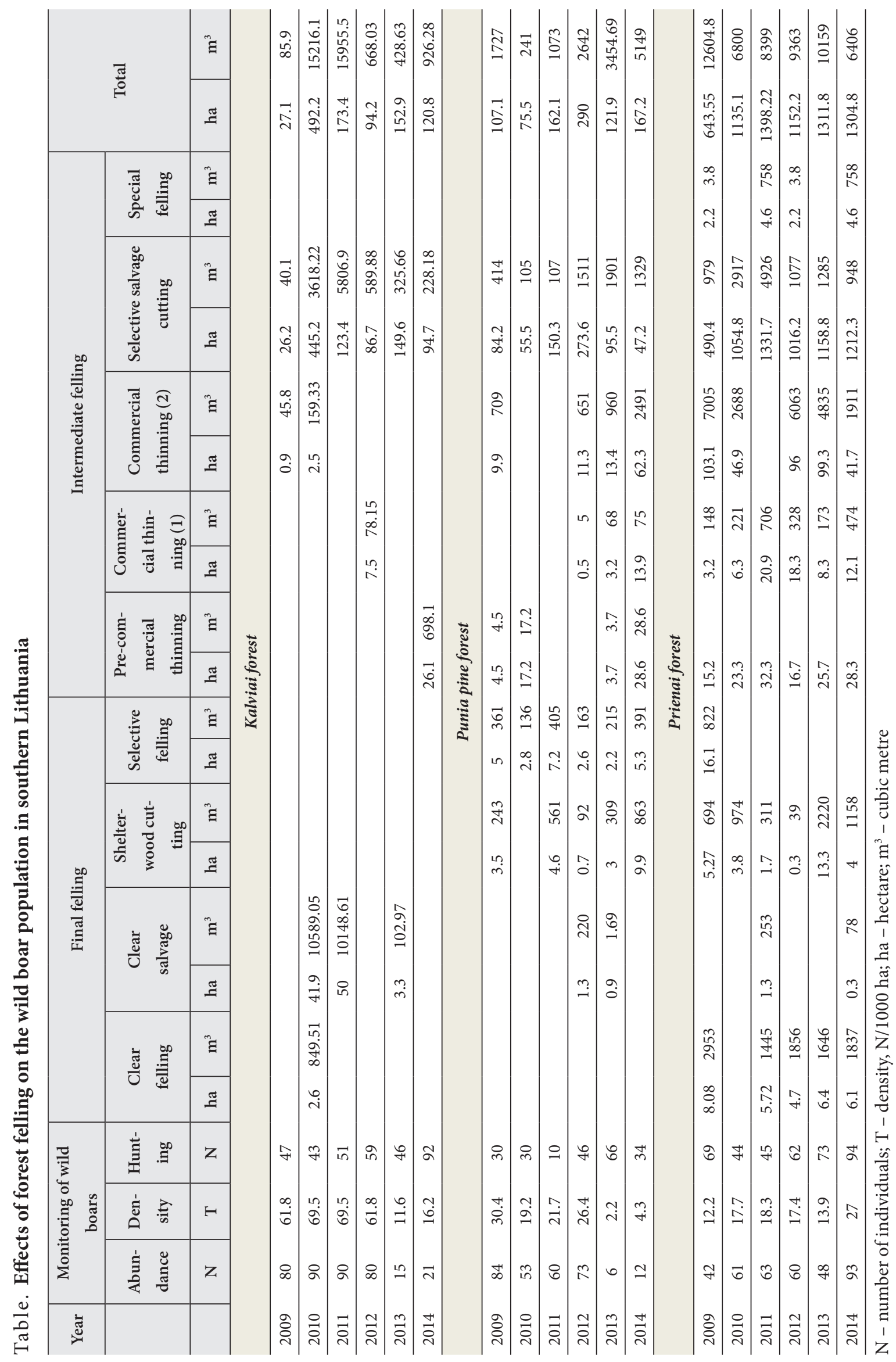


Correlation analysis was performed to identify the strength of relationships between wild boar abundance/density and felling types. In the six-years observation period, a weak positive correlation between wild boar abundance and total felling rate in hectares was observed $(r=0.28)$ (Table). However, the abundance of wild boar was strongly correlated with total felling in $\mathrm{m}^{3}(r=0.59)$. These results illustrate that the wild boar population increases with increasing cases of felling (in hectares and in $\mathrm{m}^{3}$ ). We suppose that low levels of clear felling was carried out in small study areas, meanwhile selective salvage cutting in large plots has led to a positive effect in the growth of the wild boar population.

The Kalviai forest is dominated by selective salvage cutting, which is controlled by a small volume of wood over a large area (Table). This cutting does not impair the nutritional quality and does not reduce the number of hiding places. We found that there was a weak positive relationship between wild boar abundance and selective salvage cutting (ha) $(r=0.25)$; meanwhile, a stronger positive relationship was obtained by investigating the relationship between the measure of wood cutting in $\mathrm{m}^{3}$ $(r=0.58)$ (Fig. 2). The correlation coefficient of 0.59 indicates a strong positive correlation between wild boar abundance and total volume of wood cutting $\left(\mathrm{m}^{3}\right)$, because in Kalviai forest, the largest amount of timber volume $\left(\mathrm{m}^{3}\right)$ is felled by clear salvage felling that consists of a relatively small area but a large amount of wood (Fig. 3). In the interpretation of such

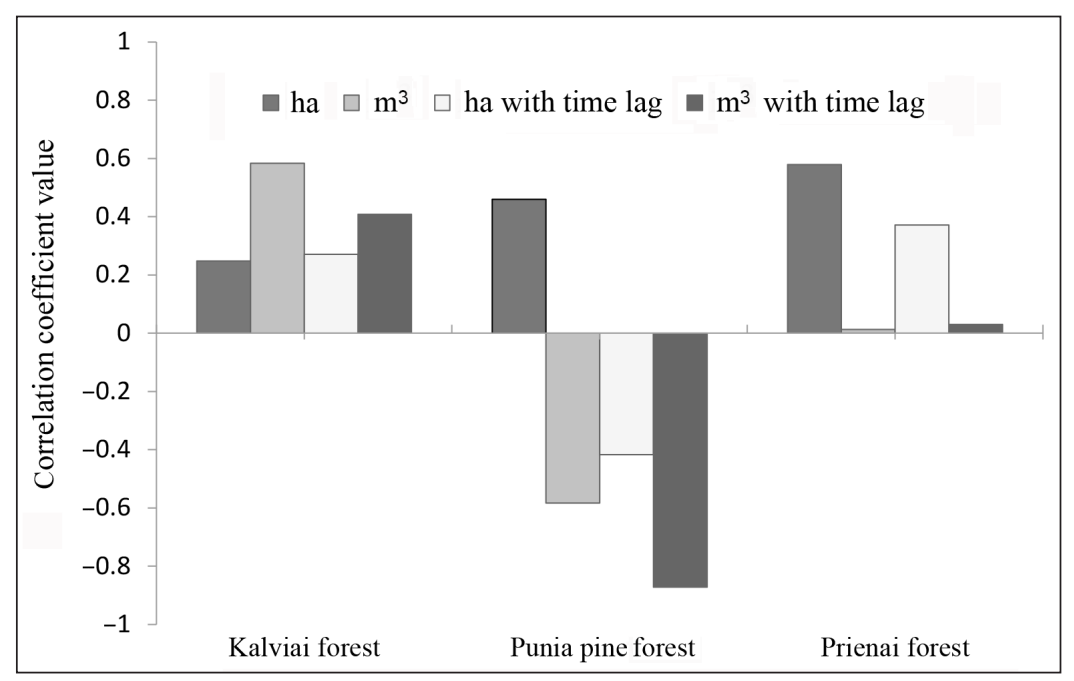

Fig. 2. Estimates of correlation coefficients of the abundance of wild boars and selective salvage cutting

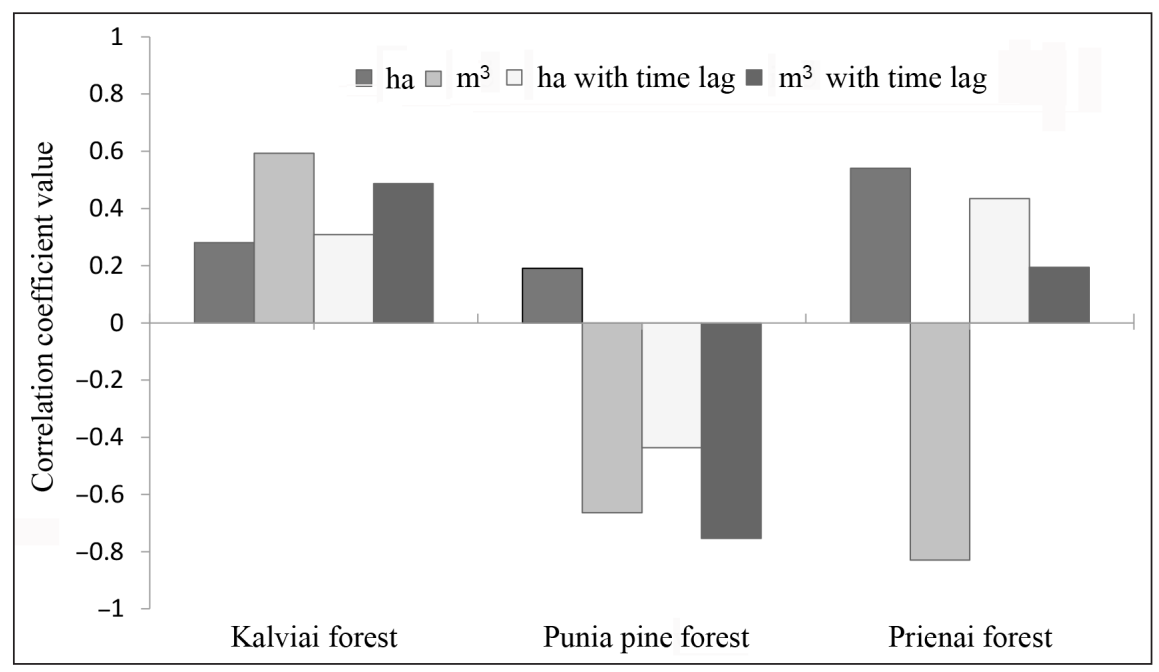

Fig. 3. Estimates of correlation coefficients of the abundance of wild boars and deforestation 
correlations, we can conclude that clear cutting affects the soil mechanically during the felling process and after the preparation of logging sites for planting. This improves the nutritional base of wild boars by grubbing and searching for cockchafers in the soil. Clear salvage cutting is carried out in premature and mature stands that are not attractive to wild boars. Forestry measures alter forest succession that can affect the ungulates by changing forage quantity and quality (Schrempp et al., 2019).

A similar situation was found in Punia pine forest, where the positive correlation between wild boar abundance and total felling (ha) was weak $(r=0.19)$; it might be explained by prevalent selective salvage cutting (Fig. 3). Moreover, the results indicated a strong negative correlation $(r=-0.67)$ between the abundance of wild boar and the volume of wood cutting $\left(\mathrm{m}^{3}\right)$ (Fig. 3). In contrast to Kalviai forest, the observed negative correlation implies that the number of wild boars decreased with increasing felling intensity. The correlation is further strengthened if a one-year change is taken into account $(r=-0.75)$ (Fig. 3). These results demonstrated that the changes in the wild boar population were affected not only by the felling of the current year, but also by that of the previous year. Assessment of the correlation coefficient value $(r=0.46)$ between the abundance of wild boar and selective salvage cutting revealed that this felling type had a positive effect on the wild boar population (Fig. 2). A similar pattern is also reported by other authors (Gasperini et al., 2016). They found that that different types of forest management had strong positive effects on the density of rodent population. A sufficiently strong correlation was observed between the quantity of wild boar and total felling in $\mathrm{m}^{3}(r=-0.67)$. Contrary to the results obtained in Kalviai forest, this relationship is negative and could be explained by the impact of increased cutting intensity on the decrease in the number of wild boars. This finding is unsurprising considering that a bigger volume of logging is realized by final cutting of shelterwood and selective felling. In these types of thinning, the intent is to harvest a large volume of timber $\left(\mathrm{m}^{3}\right)$ over a large area, thus reducing the stocking level of a stand. Therefore, conditions of breeding and hiding places are affected by a reduced selection of the habitat. According to Son et al. (2017), tree affects the abundance of animals due to their preferences of the habitat. Wilson and Forsman (2013) previously demonstrated that thinning reduced the abundance of some tree-dwelling rodents.

A similar trend involving a strong positive correlation between wild boar abundance and total felling in hectares $(r=0.54)$ and negative correlation with felling in $\mathrm{m}^{3}(r=-0.83)$ was also reported in Prienai forest (Fig. 3). Clearly, there was a weak correlation in terms of time, indicating that the felling of the current year has a greater impact for wild boar subpopulation from Prienai forest compared to the felling of the previous year. The selective salvage cutting dominates in Prienai forest and the correlation coefficient of 0.57 indicates a strong positive correlation (Fig. 2). These results confirmed that selective salvage cutting improved nutritional conditions for wild boar. The reason for the negative correlation of felling in $\mathrm{m}^{3}$ was similar to that in Kalviai forest. The maximum volume of timber $\left(\mathrm{m}^{3}\right)$ was harvested by final cutting of shelterwood and intermediate cutting of commercial thinning (Table). These types of felling may be associated with a reduction of the stocking level of stands and activities in stands of all ages in a large area. Moreover, in this situation the conditions of breeding and hiding places worsened, because females of wild boars choose shaded forest areas and high stocking level plots suitable for the birth of their young.

\section{CONCLUSIONS}

Our results demonstrated that some types of felling had a negative effect on the density of the wild boar population in south Lithuania. Further analysis of data collected over a larger area is needed to check these findings.

Received 19 April 2020 Accepted 19 May 2020 


\section{References}

1. Acevedo P, Delibes-Mateos M, Escudero MA, Vicente J, Marco J, Gortázar C. Environmental constraints in the roe deer (Capreolus capreolus Linnaeus, 1758) colonization sequence across the Iberian Mountains (Spain). J Biogeogr. 2005; 32: 1671-80.

2. Acevedo P, Escudero MA, Muñoz R, Gortázar C. Factors affecting wild boar abundance across an environmental gradient in Spain. Acta Theriol. 2006; 51: 327-36.

3. Apollonio M, Andersen R, Putman R. In: European Ungulates and their Management in the 21st Century. 1st ed. Cambridge: Cambridge University Press; 2010.

4. Avgar T, Baker JA, Brown GS, Hagens JS, Kittle AM, Mallon EE, et al. Space-use behaviour of woodland caribou based on a cognitive movement model. J Anim Ecol. 2015; 84: 1059-1070.

5. Baleišis R, Bluzma P, Balčiauskas L. Lietuvos kanopiniai žvèrys. 3rd ed. Vilnius: Akstis; 2003. p. 216.

6. Ballari SA, Barrios-García MN. A review of wild boar Sus scrofa diet and factors affecting food selection in native and introduced ranges. Mammal Rev. 2014; 44: 124-34.

7. Cahill S, Limona F, Gracia J. Spacing and nocturnal activity of wild boar Sus scrofa in a Mediterranean metropolitan park. Wildl Biol. 2003; 9: 13-33.

8. Gasperini S, Mortelliti A, Bartolommei P, Bonacchi A, Manzo E, Cozzolino R. Effects of forest management on density and survival in three forest rodent species. Forest Ecol Manag. 2016; 382: 151-60.

9. Gethöffer F, Sodeikat G, Pohlmeyer K. Reproductive parameters of wild boar (Sus scrofa) in three different parts of Germany. Eur J Wildl Res. 2007; 53: 287-97.

10. Herrero J, García-Serrano A, García-González R. Reproductive and demographic pa- rameters in two Iberian wild boar Sus scrofa populations. Acta Theriol. 2008; 53(4): 355-64.

11. Keuling O, Stier N, Roth M. How does hunting influence activity and spatial usage in wild boar Sus scrofa L.? Eur J Wildl Res. 2008; 54(4): 729-37.

12. Lacolina L, Pertoldi C, Amills M, Kusza S, Megens HJ, Bâlteanu VA, et al. Hotspots of recent hybridization between pigs and wild boars in Europe. Sci Re. 2018; 8: 17372.

13. Lombardini M, Meriggi A, Fozzi A. Factors influencing wild boar damage to agricultural crops in Sardinia (Italy). Curr Zool. 2017; 63(5): 507-14.

14. Long RA, Rachlow JL, Kie JG. Effects of season and scale on response of elk and mule deer to habitat manipulation. J Wildl Manage. 2008; 72: $1133-42$.

15. Massei G, Kindberg J, Licoppe A, Dragan G, Sprem N, Kamler J, et al. Wild boar populations up, numbers of hunters down? A review of trends and implications for Europe. Pest Manag Sci. 2015; 71(4): 492-500.

16. Navasaitis A, Pètelis K. Medžioklè. Kaunas: Lututè; 1998. p. 316.

17. Nores C, Llaneza L, Alvarez A. Wild boar Sus scrofa mortality by hunting and wolf Canis $l u$ pus predation: an example in northern Spain. Wildlife Biol. 2008; 14: 44-51.

18. Schrempp TV, Rachlow JL, Johnson TR, Shipley LA, Long RA. Aycrigg JL, Hurley MA. Data from: Linking forest management to moose population trends: the role of the nutritional landscape. PloS One. 2019; 14(7): e0219128.

19. Son SH, Hwang HS, Lee JK, Eom TK, Park CR, Lee EJ, et al. Influence of tree thinning on the abundance of mammals in a Japanese larch Larix kaempferi plantation. Anim Cells Syst. 2017; 21(1): 70-5.

20. Stergar M, Jerina K. Wildlife and forest management measures significantly impact red deer population density. Šumarski list. 2017; 141. 3(4): 139-50. 
21. Thurfjell H, Spong G, Ericsson G. Effects of hunting on wild boar Sus scrofa behaviour. Wildlife Biol. 2013; 19: 87-93.

22. Tolon V, Dray S, Loison A, Zeileis A, Fischer C, Baubet E. Responding to spatial and temporal variations in predation risk: space use of a game species in a changing landscape of fear. Can J Zool. 2009; 87: 1129-37.

23. Wilson TM, Forsman ED. Thinning effects on spotted owl prey and other forest-dwelling small mammals. In: Anderson PD, Ronnenberg KL, editors. Gen. Tech. Rep. PNWGTR-880. Portland, OR: U.S. Department of Agriculture, Forest Service, Pacific Northwest Research Station. 2013; 79-90.
Tomas Barkauskas, Loreta Griciuvienè, Olgirda Belova, Nomeda Bratčikovienè

\section{MIŠKININKAVIMO POVEIKIS ŠERNŲ POPU- LIACIJAI PIETŲ LIETUVOJE}

\section{Santrauka}

Šio tyrimo tikslas buvo ịvertinti skirtingų miško kirtimo rūšių įtaką šernų populiacijos skaitlingumui Pietų Lietuvoje. Tyrimas buvo atliktas Prienų šilo, Punios šilo ir Kalvių miško dalyje. Duomenys apie šernų populiacijos skaitlingumą ir medžioklès dinamiką buvo surinkti iš šešių medžioklès sezonų (2008-2014 m.). Rezultatai rodo, kad kai kurie kirtimų tipai turèjo neigiamą ittaką šernų populiacijos gausumui Pietinèje Lietuvos dalyje. Pastebejome, kad šernų populiacijos pokyčius paveikè ne tik einamųjų, bet ir praejusių metų kirtimai. Norint patvirtinti šias išvadas, reikalingi platesni tyrimai.

Raktažodžiai: Sus scrofa, miškininkavimas, Pietų Lietuva 